\title{
Kepemimpinan Strategis dalam Masa Krisis Pandemi Covid-19 (Belajar dari Pemimpin Daerah Kota Tegal)
}

\author{
Joko Aji Wibowo*, Maria Puspitasari \\ Kajian Ketahanan Nasional Universitas Indonesia \\ *Correspondence email: joko.aji@ui.ac.id; puspitasari11@ui.ac.id
}

\begin{abstract}
Abstrak. Krisis pandemi Covid-19 menjadi ujian bagi Pemimpin Daerah dalam menunjukkan karakteristik kepemimpinan strategisnya. Salah satu yang menarik dikaji adalah kebijakan yang dilakukan oleh Wali Kota Tegal, yang sempat menimbulkan kontroversi karena pengumuman penerapan local lockdown dengan cara menutup akses jalan protokol dalam kota dan jalan penghubung antar kampung di bawah kepemimpinannya. Penelitian ini dibuat untuk tujuan mengidentifikasi dan menganalisis kepemimpinan strategis Pemimpin Daerah Kota Tegal dalam mengatasi krisis pandemi Covid-19 dan dampak dari kepemimpinan tersebut terhadap ketahanan nasional Indonesia. Metode yang digunakan adalah pendekatan kualitatif dengan teknik analisis deskriptif dan pengumpulan data sekunder melalui kajian literatur. Hasil analisis kepemimpinan strategis Wali Kota Tegal menunjukkan upaya memfasilitasi kemampuan sistem sosial di Kota Tegal untuk beradaptasi dengan kondisi pandemi Covid-19 dan belajar untuk mengatasi masalah-masalah yang timbul. Analisis strategisnya yaitu dengan menerapkan strategic leadership melalui tujuan, cara dan alat yang digunakan sesuai dalam menekan penyebaran Covid-19 di wilayah Kota Tegal. Peranan nilai kemanusiaan dan kepedulian serta kerja sama semua pihak dinilai efektif dalam menangani krisis. Dengan upaya tersebut dapat membangun satisfaction yang lebih kuat dan capaian pada pelibatan stakeholder yang lebih mewakili sisi rakyat.
\end{abstract}

Kata kunci : Kepemimpinan strategis; pemimpin daerah; komunikasi krisis; ketahanan nasional

Abstract. The Covid-19 pandemic crisis is a test for Regional Leaders in showing their strategic leadership characteristics. One of the things that is interesting to study is the policy carried out by the Mayor of Tegal, which had caused controversy due to the announcement of the implementation of a local lockdown by closing the access to the inner city protocol roads and connecting roads between villages under his leadership. This research was made for the purpose of identifying and analyzing the strategic leadership of the Regional Leaders of the City of Tegal in overcoming the Covid-19 pandemic crisis and the impact of this leadership on Indonesia's national resilience. The method used is a qualitative approach with descriptive analysis techniques and secondary data collection through literature review. The results of the analysis of the Tegal Mayor's strategic leadership show efforts to facilitate the ability of the social system in Tegal City to adapt to the conditions of the Covid-19 pandemic and learn to overcome problems that arise. The strategic analysis is to implement strategic leadership through the objectives, methods and tools used to reduce the spread of Covid-19 in the Tegal City area. The role of human values and concern and cooperation of all parties is considered effective in dealing with crises. With these efforts, it can build stronger satisfaction and achievements in involving stakeholders who are more representative of the people's side.

Keywords: Strategic leadership; regional leader; crisis communication; national resilience

\section{PENDAHULUAN}

Krisis pandemi Covid-19 melanda hampir di seluruh negara di dunia dalam waktu yang cepat. Berdasarkan data dari worldmeters.info tanggal 12 Januari 2021 bahwa kasus Covid-19 di seluruh dunia mencapai 91.269.083 kasus, angka kematian akibat Covid-19 berjumlah 1.951 .792 jiwa dan angka pasien sembuh mengalami kenaikan, yaitu tercatat 65.207.987 orang sembuh dari Covid-19.

Krisis ini menjadi tantangan sekaligus ancaman bagi pemimpin negara di dunia. Oleh karena itu, pentingnya seorang pemimpin menyusun dan menerapkan strategi yang tepat melalui komunikasi yang baik kepada publik dalam menghadapi krisis yang menghantam wilayahnya. Diketahui sejumlah pemimpin negara-negara di dunia telah melakukan berbagai upaya dalam mengatasi pandemi Covid-19. Meski demikian, diketahui pula bahwa pemimpin di level daerah dalam beberapa hal menunjukkan inovasi dan kemampuannya untuk menjadi pelopor dalam melakukan penanganan pandemi Covid-19.

Salah satunya dapat dilihat pada kasus di India, dimana beberapa Kepala Daerahnya menerapkan lockdown atau menerapkan Pasal 144 Kitab UndangUndang Hukum Pidana (KUHP) India tentang pelarangan aktivitas ramai di tempat umum. Beberapa Kepala Daerah di Amerika Serikat seperti New York menerapkan kebijakan lain seperti work from home, belajar di rumah dan menutup perbelanjaan yang tidak berkaitan dengan kebutuhan pokok masyarakat. Langkah pemerintah daerah segera menerapkan kebijakannya dikarenakan pemerintah daerah memang menjadi garda terdepan sebelum suatu masalah ditetapkan sebagai masalah nasional. Sehingga jika berhasil menjaga daerahnya, mereka akan menuai pujian karena dianggap sebagai pemimpin yang berhasil, namun jika gagal maka akan terjadi hal yang sebaliknya (Felix, 2020).

Di Indonesia sejumlah Kepala Daerah sigap menerapkan kebijakan sejak awal merebaknya Covid-19 
di Indonesia. Hal ini terjadi karena belum ada arahan yang jelas dari pemerintah pusat. Salah satu yang menarik untuk dicermati adalah pada kasus di Kota Tegal, dimana kepala daerahnya melakukan sejumlah kebijakan, yaitu dimulai dengan menerapkan local lockdown dengan cara menutup akses jalan protokol dalam kota dan jalan penghubung antar kampung.

Wali Kota Tegal secara langsung mengumumkan bahwa daerah di bawah kepemimpinannya menerapkan PPKM (Pemberlakuan Pembatasan Kegiatan Masyarakat). Sejak tanggal 11 Januari 2021, pemerintah pusat menggunakan istilah PPKM sebagai penamaan lain pembatasan kegiatan masyarakat yang diserahkan kepada pemerintah daerah untuk menyusun kebijakan tergantung pada situasi yang ada pada masing-masing daerah.

Hal tersebut menimbulkan kontroversi. Akan tetapi menarik mencermati bagaimana kebijakan ini dilihat dari segi kepemimpinan stratejik. Meski menimbulkan kontroversi, nyatanya kebijakan tersebut dinilai berhasil menurunkan angka kasus Covid-19. Sebagaimana dilihat dari keberhasilan Kota Tegal setelah PSBB tahap kedua (bulan Mei 2020) dinyatakan nol kasus Covid-19 dan menjadi zona hijau. Namun,disisi lain setelah penerapan era new normal ditemukan kembali kasus positif Covid19 di Kota tegal.

Dalam artikel ini akan dibahas mengenai bagaimana analisis kepemimpinan strategis Kepala Daerah kota Tegal dalam mengatasi krisis pandemi Covid-19 dan bagaimana dampak dari kepemimpinan tersebut terhadap ketahanan nasional Indonesia.

\section{METODE}

Pendekatan yang digunakan dalam penelitian ini adalah pendekatan kualitatif. Penelitian kualitatif merupakan metode untuk mengeksplorasi dan memahami makna yang oleh sejumlah individu atau sekelompok orang dianggap berasal dari masalah sosial atau kemanusiaan (Creswell, 2009). Pengumpulan data dilakukan melalui data sekunder, dengan data yang digunakan berasal dari studi kepustakaan, studi dokumen yang bersumber dari artikel dan data dari instansi terkait. Teknik analisis data menggunakan analisis deskriptif, dimana analisis deskriptif ini digunakan sebagai analisis sederhana yang bertujuan untuk menafsirkan informasi yang didapat dalam bentuk tabel, grafik, dan diagram (Yoesgiantoro, 2018)

\section{HASIL DAN PEMBAHASAN}

Pemerintah Kota Tegal pertama kali menerapkan kebijakan local lockdown pada tanggal 30 Maret 2020. Hal tersebut dilakukan karena ada satu orang warga Kota Tegal dinyatakan positif terinfeksi Covid-19 dan 14 Pasien Dalam Pengawasan (PDP). Penerapan local lockdown ini dianggap sebagai kebijakan yang tidak populis dan merupakan keputusan yang sulit dan dilematis.
Keberanian Wali Kota Tegal dalam mengambil keputusan tersebut didasari setelah dilakukan kajian bahwa saat itu tidak ada alternatif lain yang tepat dalam mengatasi penyebaran Covid-19 selain local lockdown atau karantina wilayah. Penerapan kebijakan local lockdown hanya dilakukan pada jalan protokol dalam kota dan antar kampung, dengan tidak menutup akses jalan provinsi dan nasional. Di samping itu, Pemerintah Kota Tegal juga melibatkan masyarakat dengan membentuk Relawan Mandiri Covid-19.

Pemerintah Kota Tegal juga menerapkan PSBB sampai dua tahap setelah mendapatkan izin dari Kementerian Kesehatan. Dengan kebijakan tersebut menunjukkan hasil yang baik yaitu terlihat kasus positif Covid-19 terkendali, pasien dalam pengawasan (PDP) menurun, orang dalam pemantauan (ODP) terpantau terkendali, serta meningkatnya kesadaran masyarakat dalam mencegah penularan maupun penyebaran virus corona.

Setelah dinyatakan Kota Tegal sebagai zona hijau dari penyebaran Covid-19, maka pada tanggal 1 Juni 2020 Pemerintah Kota Tegal menerapkan era new normal dan membubarkan Gugus Tugas Covid-19. Walau demikian, Wali Kota Tegal sebagai pemimpin daerah tersebut tetap menghimbau kepada seluruh masyarakat kota Tegal untuk tetap memperhatikan dan menjalankan protokol kesehatan dalam era new normal.

Setelah era new normal dijalankan ternyata pada Bulan Agustus 2020 ditemukan adanya peningkatan kasus positif Covid-19 pada tanggal 5 Agustus 2020 sebanyak lima orang. Kemudian terjadi peningkatan yang signifikan pada tanggal 10 Agustus 2020 sebanyak 46 orang terkonfirmasi positif Covid-19 (Lilisnawati, 2020). Oleh karena itu, Wali Kota Tegal kembali menghimbau kepada masyarakat untuk bersama-sama mengatasi penyebaran Covid-19 dengan menerapkan protokol kesehatan secara ketat dan menyiapkan tempat isolasi mandiri.

Namun, permasalahan terkait kepatuhan masyarakat muncul kembali dimana pada bulan September 2020 terjadi kelengahan aparat daerah kota Tegal dengan adanya acara Pesta Dangdutan di Lapangan Teuku Cik Ditiro Tegal Selatan. Dalam acara tersebut terjadi kerumunan warga dalam jumlah besar dengan tidak mengindahkan protokol kesehatan. Oleh karena itu, kepemimpinan strategis pemimpin daerah kota Tegal benar-benar diuji dalam mengatasi krisis akibat pandemi Covid-19. Dalam hal ini, kepemimpinan strategis tidak hanya dilihat dari segi ketika menerapkan kebijakan melainkan termasuk dalam mengatasi masalah-masalah yang timbul.

Berikut analisis kepemimpinan strategis Pemimpin Daerah Kota Tegal dalam mengatasi pandemi Covid-19: 


\section{Strategic Leadership}

Seorang pemimpin yang dapat menerapkan strategic leadership (kepemimpinan strategis) berarti pemimpin tersebut memiliki kemampuan konseptual untuk membuat keputusan strategis. Sedangkan strategi itu sendiri merupakan rencana kegiatan untuk mencapai tujuan. Di samping itu, menurut Olson dan Simerson (2015) bahwa kepemimpinan melibatkan pemimpin yang mempengaruhi kelompok, organisasi atau komunitas, dimana harus melibatkan tim atau kelompok tersebut dalam transaksi agar kepemimpinan terjadi. Hal ini terlihat dalam sinergi kepemimpinan strategis yang dilakukan oleh Wali Kota Tegal yaitu H. Dedy Yon Supriyono, S.E., M.M. dan Wakil Wali Kota Muhamad Jumadi, S.T., M.M. dalam mengatasi wabah pandemi Covid-19 di wilayah kepemimpinannya.

Sejak awal merebak wabah Covid-19 pada bulan Maret 2020 Pemerintah Kota Tegal langsung mengambil langkah cepat sesaat setelah kota Tegal terdapat kasus penyebaran Covid-19 dengan berbagai upaya melalui strategi khusus dalam mengatasi penyebaran wabah tersebut. Sebagaimana disampaikan Wakil Wali Kota Tegal dalam Forum diskusi United Cities and Local government Asia Pasific (UCLG ASPAC) yang membahas strategi penegakan disiplin protokol kesehatan oleh Pemerintah Daerah dalam menghadapi Covid-19 melalui sambungan video conference.

Menurut Guillot (2003) bahwa strategi yang dilakukan pemimpin strategis, menghubungkan tiga hal yaitu tujuan, cara dan alat yang digunakan. Adapun analisis strateginya sebagai berikut:

1. Tujuan untuk menekan penyebaran Covid-19 di wilayah Kota Tegal.

2. Cara yang dilakukan yaitu local lockdown dengan menutup akses jalan menggunakan beton $M C B$ (Moveable Concrete Barier) untuk membatasi kegiatan manusia, mematikan lampu penerangan jalan umum di malam hari untuk mencegah kerumunan, Pembatasan Sosial Berskala Besar (PSBB). Pada awal merebaknya Covid-19, Pemkot mengambil upaya intervensi pertama dengan melaksanakan local lockdown pada 30 Maret 2020. Kedua, dilakukan isolasi wilayah, dan intervensi ketiga yakni pemberlakuan PSBB dari 23 April-22 Mei 2020, relaksasi, sampai kemudian menuju kebijakan new normal (Tm, 2020).

Cara berikutnya melakukan era new normal dengan protokol kesehatan yang ketat dan menggandeng masyarakat melalui pembentukan Relawan Mandiri Covid-19 yang diketuai langsung Wakil Wali Kota Tegal serta beranggotakan berbagai komunitas di masyarakat dan institusi perusahaan. Masyarakat Kota Tegal paham bagaimana membantu orang yang terpapar virus Covid-19, bukan menjauhi atau menstigma negatif melainkan dengan saling membantu jika di lingkungannya ada yang positif Covid-19. Masyarakat bahu-membahu membantu dan menjamin ketersediaan kebutuhan pangan bagi penderita Covid-19 yang menjalani isolasi mandiri di tempat tinggalnya.

3. Alat yang digunakan yaitu regulasi Perwal No.13 Tahun 2020 tentang Pencegahan Penularan Covid-19 dan Komunitas Jakwir Pentol yang merupakan realisasi menggandeng masyarakat dalam penanganan Covid-19. Arti Jakwir adalah teman baik atau pendekatan sikap dengan keterbukaan, dengan kata lain berteman dengan Covid-19 sedangkan pentol artinya hebat. Teman yang baik selalu menguatkan dan terbuka dengan tatanan kehidupan baru (new normal).

Jakwir Pentol ini direalisasikan dalam kehidupan masyarakat sehari-hari, seperti menjalankan protokol kesehatan pada semua lini, wirausaha dan ekonomi harus tetap berjalan dan semakin baik, memperkuat interaksi, serta koordinasi lintas batas. Di samping itu, tentunya memanfaatkan media baik itu media cetak, media elektronik dan media online sebagai alat dalam sosialisasi atau kampanye publik terkait strategi untuk memperoleh dukungan.

Strategi tersebut ternyata menunjukan hasil nyata dengan dinyatakan Kota Tegal sebagai wilayah di Jawa tengah dengan nol kasus Covid-19 setelah dua tahap pemberlakuan PSBB per 19 Mei 2020 (Iqbal, 2020). Sebelumnya selama penanganan kasus Covid-19 terlihat kasus positif Covid-19 terkendali, pasien dalam pengawasan (PDP) menurun, orang dalam pemantauan (ODP) terpantau terkendali, serta meningkatnya kesadaran masyarakat dalam mencegah penularan maupun penyebaran virus corona.

Sekjen UCLG ASPAC memberikan apresiasi atas keberhasilan Pemerintah Kota Tegal dalam mengatasi pandemi Covid-19 di wilayahnya serta menghimbau kepada Kepala Daerah lainnya untuk meniru langkah inovatif tersebut dalam mengatasi penyebaran Covid-19 di wilayah masing-masing. Bahkan, Komisi A DPRD Jakarta juga memberikan apresiasi pada Wali Kota Tegal atas keberhasilan dalam penanganan Covid-19 sehingga Kota Tegal menjadi zona hijau. Di samping itu, Komisi A DPRD Jakarta juga melakukan koordinasi dan studi komparasi keberhasilan Kota Tegal dalam penanganan dan pengendalian Covid-19, manajemen bantuan sosial, serta peran serta ormas dalam PSBB.

Menurut Guillot (2003) bahwa pemimpin strategis harus mengenali dan memahami komponen lingkungan strategis, yaitu keamanan nasional, domestik, militer dan lingkungan internasional. Dalam lingkungan keamanan, pemimpin strategis harus memahami prioritas dan peluang serta ancaman dan risiko yang dihadapai.

Dalam strategi yang diterapkan oleh Pemerintah Kota Tegal, terlihat memperhatikan komponen lingkungan strategis dalam kebijakan yang diterapkannya, yaitu terkait komponen keamanan dan domestik dengan memperhatikan persoalan politik dan 
ekonomi akibat pandemi Covid-19. Hal tersebut dapat dilihat dari kebijakan menjalankan protokol kesehatan pada semua lini, tetapi wirausaha dan ekonomi juga harus tetap berjalan dan semakin baik, memperkuat interaksi, serta melakukan koordinasi lintas batas.

Komisi A DPRD Jakarta yang melakukan studi komparasi di Kota Tegal juga mengakui banyak hal positif yang didapatkan dalam penanganan Covid-19, seperti manajemen bantuan sosial yang ternyata bagus, termasuk pengendalian harga sembako dan APD yang tidak melonjak, kompaknya ormas Kota Tegal dalam PSBB, serta Pemkot mampu menjaga keamanan wilayahnya melalui local lockdown, isolasi wilayah dan setelah disetujui Kementerian Kesehatan melaksanakan PSBB sampai dua kali.

Dengan demikian, dari segi biaya yang dikeluarkan, Kota Tegal dianggap paling hemat, termasuk untuk pembelanjaan sembako dan pembelian APD juga paling rendah, serta terkait pemulihan ekonomi dan pembubaran gugus tugas Covid-19 menjadi yang pertama dan tercepat.

\section{Manajemen Krisis}

Kepemimpinan merupakan proses yang serupa dengan manajemen dalam banyak hal. Kepemimpinan mencakup pengaruh dan bekerja dengan orang lain, sama seperti manajemen (Northouse, 2013). Dalam hal ini manajemen krisis menurut Coombs (1999) dibagi dalam tiga tahap, yaitu tahap prakrisis, krisis dan pascakrisis.

Pertama, tahap prakrisis terdiri dari tiga subtahap, yakni deteksi sinyal, pencegahan dan persiapan krisis. Kedua, tahap krisis yang dibentuk oleh dua subtahapan, yaitu pengenalan krisis dan penanganan krisis. Pada tahap ini, bagaimana respon organisasi terhadap situasi krisis serta komunikasinya dengan para pemangku kepentingan dan bagaimana organisasi menangani krisis tersebut. Tahap ini mencakup respon organisasi terhadap apa yang sebenarnya terjadi dengan rencana manajemen krisis yang dilaksanakan serta melakukan kajian atau literasi yang tepat. Ketiga, tahap pascakrisis, fokus pada tahapan ini adalah mempersiapkan diri untuk menghadapi potensi krisis lanjutan. Krisis mungkin tidak sehebat sebelumnya, tetapi organisasi tetap mengawasi media dan kegiatan kelompok pemangku kepentingan.

Berikut analisis manajemen krisis yang dilakukan Pemimpin Daerah Kota Tegal dalam mengatasi krisis pandemi Covid-19:

\section{Tahap Krisis}

Dalam kasus ini tahap pertama adalah pada tahap krisis karena sudah terjadi penyebaran Covid-19 di wilayah Kota Tegal. Menurut Ulmer, dkk (2007) dalam Puspitasari (2016) bahwa salah satu pendekatan yang dinilai efektif untuk menangani krisis adalah kembali pada nilai dasar yang dianut organisasi. Dalam hal ini, nilai yang dianut Pemerintah Kota Tegal dalam mengatasi krisis pandemi Covid-19 adalah demi kemanusiaan dan kepedulian. Kemanusiaan merupakan pandangan filosofis dan sistem nilai yang menekankan pada keunikan dan melekat pada manusia. Sedangkan kepedulian merupakan konsep yang secara etis terkait dengan tugas umat manusia untuk menolong sesama dan secara spesifik menuntut adanya respon yang mendukung individu akibat adanya malapetaka atau bencana yang menimpanya (Puspitasari, 2016).

Nilai kemanusiaan dan kepedulian terlihat pada kebijakan yang diterapkan oleh Pemerintah Kota Tegal. Respon dan komunikasi dari pemimpin daerah Kota Tegal secara langsung mengumumkan bahwa daerah di bawah kepemimpinannya akan menerapkan local lockdown dengan cara menutup akses jalan protokol dalam kota dan jalan penghubung antar kampung. Argumen Wali Kota Tegal jelas yaitu untuk memutus mata rantai penyebaran Covid-19 di wilayahnya (Agustino, 2020).

Keputusan tersebut diambil karena tidak ada alternatif lain dalam memutus penyebaran Covid-19 yang terjadi secara masif dan cepat serta tidak adanya arahan yang jelas dari pemerintah pusat dalam mengendalikan Covid-19 sehingga mendorong pemerintah daerah lainnya mengimplementasikan kebijakannya sendiri yang dianggap mampu mengendalikan penyebaran Covid-19 di daerahnya masing-masing. Setelah melakukan kajian, akhirnya Pemerintah Kota Tegal melakukan isolasi wilayah dan PSBB sampai dua kali setelah disetujui oleh Kementerian Kesehatan. Di samping itu Pemkot Tegal juga memberdayakan masyarakat dalam penanganan krisis Covid-19 melalui Jakwir Pentol sebagai wadah Relawan Mandiri Covid-19 melibatkan berbagai komunitas di masyarakat dan institusi perusahaan.

Setelah PSBB tahap dua berakhir, Kota Tegal dinyatakan sebagai zona hijau Covid-19. Bahkan, pemulihan ekonomi dan pembubaran gugus tugas Covid19 Kota Tegal menjadi yang pertama dan tercepat. Walau demikian, setelah gugus tugas dibubarkan akan ada tim relawan dan Pemerintah Kota Tegal menerapkan aturan new normal dengan menjalankan protokol kesehatan secara ketat (Setiadi, 2020). Pelaksanaan tersebut diperkuat dengan dibuatnya Perwal No.13 Tahun 2020 tentang Pencegahan Penularan Covid-19.

\section{Tahap Pascakrisis}

Setelah PSBB tahap kedua, Kota Tegal dinyatakan nol kasus Covid-19 atau zona hijau. Meskipun berada dalam zona hijau, Walikota Tegal tetap mempertahankan kebijakan ketat mengenai penerapan protokol kesehatan dan aturan-aturan PSBB guna mengantisipasi kemungkinan penyebaran kembali Covid-19 di wilayah Kota Tegal. Pasca PSBB aktifitas masyarakat dapat dilakukan seperti semula dengan aturan new normal, namun ternyata mulai ditemui kasus positif Covid-19. 
Sebagaimana data rekapitulasi kasus Covid-19 di Bulan Agustus 2020 untuk Kota Tegal ditemukan ada lima (5) kasus, meski demikian Kota Tegal tetap berada pada posisi Kota/Kabupaten terendah kasus Covid-19 se Jawa Tengah. Hal tersebut dapat dilihat pada data grafik berikut:

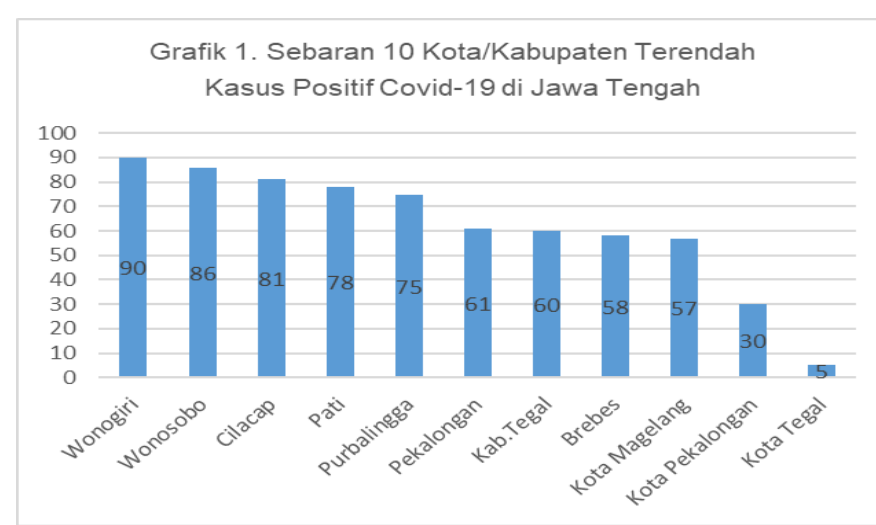

Gambar 1. Sebaran 10 Kota/Kabupaten Terendah Kasus Positif Covid-19 di Jawa Tengah

Sumber: corona.jatengprov.go.id, 5 Agustus 2020

Namun, pada bulan September 2020 terjadi kecerobohan dalam pelaksanaan protokol kesehatan dan aturan new normal pasca PSBB tahap kedua dengan adanya Pesta Dangdutan di Lapangan Teuku Cik Di Tiro Tegal Selatan yang penuh dengan kerumunan orang tanpa mengindahkan protokol kesehatan dan aturan new normal. Gubernur Jawa Tengah menegur Wali Kota Tegal dengan adanya kejadian tersebut.

Wali Kota Tegal melakukan komunikasi permohonan maaf (apologia) kepada masyarakat sebagai strategi respon komunikasi yang tepat dan mencoba meyakinkan para pemangku kepentingan bahwa terdapat pembenaran yang harus dipahami terkait kejadian tersebut. Wali Kota mengaku saat itu sedang berada di Semarang dan Pemkot mengaku "kecolongan" karena tidak mengetahui acara tersebut sebelumnya serta informasinya acara tersebut dikira tertutup hanya untuk tamu undangan saja (CNN Indonesia, 2020).

Wakil Wali Kota Tegal juga menyayangkan telah terjadi peningkatan kasus terkonfirmasi positif di Kota Tegal. Hal ini dimungkinkan karena anggapan Kota Tegal aman dari Covid-19 atau zona hijau berakibat menurunnya semangat masyarakat dalam mematuhi protokol kesehatan. Oleh karena itu, perlu ditekankan kedisiplinan dalam $3 \mathrm{M}$ (mencuci tangan, memakai masker dan menjaga jarak) serta kewaspadaan terhadap orang tanpa gejala.

Dari permasalahan tersebut dapat dicermati bahwa krisis bisa terus terjadi karena adanya masalah internal pemangku kepentingan, seperti kecerobohan yang dilakukan oleh Wakil Ketua DPRD Kota Tegal dan Kapolsek Tegal Selatan. Selain itu, krisis dapat terjadi karena faktor eksternal seperti kepatuhan masyarakat yang menurun dalam melaksanakan protokol kesehatan.
Di samping itu, media sosial juga menjadi alat yang berpengaruh menimbulkan terjadinya krisis karena informasi acara Pesta Dangdutan tersebut cepat tersebar kepada masyarakat melalui peran media sosial.

Wali Kota Tegal juga tetap menghimbau kepada seluruh masyarakat untuk tetap memperhatikan dan melaksanakan protokol kesehatan. Tindak lanjut dari kejadian tersebut bahwa pelaksana acara Dangdutan Hajatan yaitu Wakil Ketua DPRD Kota Tegal menjadi tersangka dan Kapolsek Tegal Selatan diberhentikan dari jabatannya. Pemerintah Kota Tegal juga menerbitkan Peraturan Wali Kota Tegal Nomor 29 Tahun 2020 tentang Perubahan atas Peraturan Wali Kota Tegal Nomor 13 tahun 2020 tentang Pencegahan Penularan Covid-19 di Kota Tegal.

Data per tanggal 12 Januari 2020 pukul 22.00 WIB bahwa jumlah kasus terkonfirmasi positif aktif (dirawat/dirujuk/isolasi mandiri) di Kota Tegal mengalami peningkatan yang signifikan yaitu sebanyak 86 kasus dan mengakibatkan Kota Tegal menjadi Kota/Kabupaten terendah kasus Covid-19 nomor dua setelah Salatiga. Adapun data Keseluruhan sebaran Covid-19 di Jawa Tengah dapat dilihat pada tabel berikut:

Tabel 1. Sebaran Covid-19 yang Terkonfirmasi di Jawa

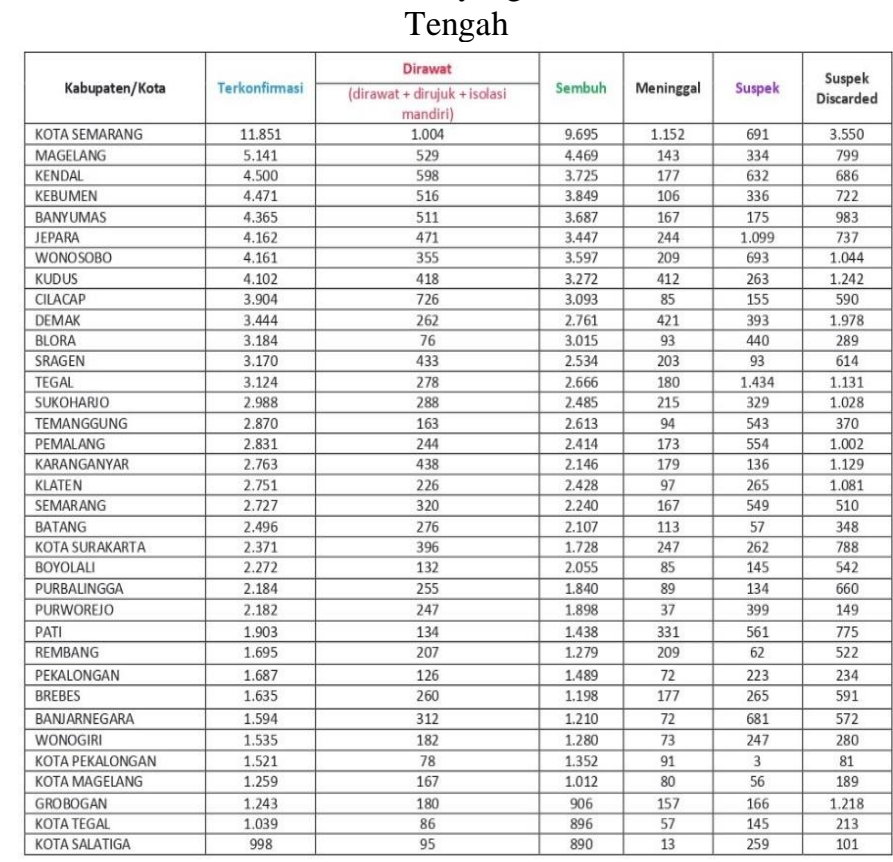

Sumber : corona.jatengprov.go.id, 12 Januari 2021 pukul 22.00 WIB

Mencermati fenomena turunnya kesadaran masyarakat pada protokol kesehatan dan meningkatnya angka penyebaran Covid-19 di Kota Tegal maka Pemerintah Kota Tegal berdasarkan arahan Wali Kota Tegal di awal tahun 2021 membeli Mesin PCR. Langkah itu dilakukan agar Kota Tegal memiliki kemampuan mendeteksi pasien terduga Covid-19 secara mandiri sehingga dengan cepat dapat melakukan tindak lanjut 
dari pasien tersebut tanpa harus menunggu lama untuk mengurangi resiko penularan yang lebih luas. Pada akhir tahun 2020 persentase kesembuhan pasien Covid-19 di kota Tegal menunjukan angka yang bagus, yaitu diatas 80 persen.

Berdasarkan data dari corona.tegalkota.go.id tanggal 31 Desember 2020 bahwa angka kesembuhan tercatat sebanyak 1.511 orang dari 1.702 orang terkonfirmasi Covid-19 (Fajar Bachruddin, 2020). Meskipun demikian, Pemerintah Kota Tegal optimis angka persentase kesembuhan pasien positif Covid-19 di Kota Tegal di tahun 2021 dapat semakin meningkat dibandingkan angka persentase kesembuhan pasien positif Covid-19 sepanjang tahun 2020. Hal itu seiring dengan tersedianya fasilitas mesin PCR yang mampu mempercepat hasil test SWAB (Galih, 2021).

Perlu diketahui bahwa setelah PSBB tahap kedua dan dinyatakan keberhasilan Kota Tegal sebagai zona hijau dalam mengatasi penyebaran Covid-19, krisis sebenarnya belum berakhir. Harusnya semua pihak aware dan menjalankan arahan Wali Kotanya untuk tetap mematuhi protokol kesehatan guna mengantisipasi potensi krisis lanjutan.

Sesuai dengan konsep teori manajamen krisis pada tahap pascakrisis ini hendaknya tetap mengawasi media dan kegiatan kelompok pemangku kepentingan, di samping itu memahami persepsi kelompok pemangku kepentingan dalam krisis yang merupakan suatu hal yang sangat penting (Coombs, 1999). Dalam kasus yang terjadi di Kota Tegal justru Wakil Ketua DPRD Kota Tegal dan Kapolsek Tegal Selatan melakukan keteledoran sehingga masyarakat mulai lengah dan enggan menjalankan aturan new normal dan protokol kesehatan, padahal pada saat awal penanganan krisis semua pihak begitu solid dan komitmen dalam melaksanakan regulasi tersebut.

\section{Dampak Terhadap Ketahanan Nasional}

Kepemimpinan strategis yang dilakukan oleh Kepala Daerah Kota Tegal dalam menghadapi krisis pandemi Covid-19 mampu meningkatkan ketahanan wilayahnya melalui ketahanan sosial yang dibentuk. Sesuai dengan konsep ketahanan sosial Cutter, dkk (2008) dalam Hanita (2020) bahwa ketahanan sosial merupakan kemampuan sistem sosial untuk merespon dan pulih dari bencana dan termasuk kondisi-kondisi yang melekat yang memungkinkan sistem untuk menyerap dampak dan mengatasi suatu peristiwa, pasca peristiwa dan proses adaptif yang memfasilitasi kemampuan sistem sosial untuk mengatur kembali, berubah dan belajar sebagai tanggapan terhadap ancaman.

Hal tersebut telah dilakukan oleh Wali Kota Tegal bersama seluruh lini dalam menghadapi krisis penyebaran Covid-19 di wilayahnya dan praktik baik ini menjadi pembelajaran sebagai acuan ketahanan untuk menyusun langkah mitigasi dan penanggulangan krisis atau bencana ke depan. Oleh karena itu, kepemimpinan strategis yang dilakukan oleh pemimpin daerah Kota Tegal dalam mengatasi krisis pandemi Covid-19 mampu mempertimbangkan prioritas dan peluang dari pembelajaran ancaman dan risiko krisis yang terjadi sehingga dapat membentuk ketahanan sosial di wilayahnya. Hal tersebut dapat mendukung ketahanan nasional Indonesia dari ancaman, gangguan, hambatan dan tantangan terutama krisis pandemi Covid-19.

\section{SIMPULAN}

Kepemimpinan strategis yang diterapkan oleh Wali Kota Tegal menunjukkan upaya memfasilitasi kemampuan sistem sosial di Kota Tegal untuk beradaptasi dengan kondisi pandemi Covid-19 dan belajar untuk mengatasi masalah-masalah yang timbul pada masa pandemi secara kolektif. Meskipun demikian, tentu saja capaian kepimimpinan strategis yang diterapkan memerlukan kerja sama dengan pemangku kepentingan yang lebih beragam yaitu mereka yang mewakili representasi masyarakat sipil. Oleh karena itu, cara yang dilakukan melalui sinergi dan komunikasi yang baik dalam menerapkan local lockdown, PSBB dan penerapan aturan era new normal. Alat yang digunakan berupa regulasi Perwal No.13 Tahun 2020 yang kemudian diperbarui Perwal No.29 Tahun 2020 tentang Pencegahan Penularan Covid-19. Selain itu, menggunakan komunitas Jakwir Pentol sebagai wadah kerja sama masyarakat dan Pemerintah Kota Tegal.

Peranan nilai kemanusiaan dan kepedulian sangat penting dalam penanganan krisis. Di samping itu, diperlukan respon yang tepat dari stakeholder dan masyarakat sebagai komunikasi krisis yang efektif. Oleh karena itu, sinergi dan pengawasan semua pihak sangat diperlukan agar keberhasilan yang telah dicapai tidak mengalami kemunduran atau bahkan kegagalan. Dengan upaya tersebut nantinya akan dapat membangun satisfaction yang lebih kuat dan capaian pada pelibatan stakeholder yang lebih mewakili sisi rakyat.

\section{DAFTAR PUSTAKA}

Achmad, Fajar Bachruddin. (2020). Di Penghujung Tahun 2020, Angka Kesembuhan Covid-19 di Kota Tegal Diklaim Capai 80 Persen. Diakses tanggal 12 Januari 2021. Dari tribunnews.com: https://banyumas.tribunnews.com/2021/01/01/dipenghujung-tahun-2020-angka-kesembuhancovid-19-di-kota-tegal-diklaim-capai-80-persen.

Agustino, Leo. (2020). Analisis Kebijakan Penanganan Wabah Covid-19 : Pengalaman Indonesia. Jurnal Borneo Administrator Vol 16 (2) : 253-270.

CNN Indonesia. (2020). Wali Kota Tegal Minta Maaf Buntut Acara Dangdutan. Diakses tanggal 11 Januari 2021. https://www.youtube.com/watch?v=5PMPiG8hk6 $\underline{\mathrm{s}}$. 
Joko Aji Wibowo dan Maria Puspitasari, Kepemimpinan Strategis dalam Masa Krisis Pandemi Covid-19 (Belajar dari

Coombs, W. T. (1999). Ongoing Crisis Management: Planning, Managing and Responding. Thousands Oak: Sage.

Coronajatengprov.go.id. (2021). Statistik Kasus Covid19 Jawa Tengah. Diakses tanggal 12 Januari 2021.

Dari corona.jatengprov.go.id:https://corona.jatengprov. go.id/data.

Creswell, JW. (2009). Research Design : Pendekatan Kualitatif, Kuantitatif, dan Mixed. Yogyakarta: Pustaka Pelajar.

Galih. (2021). Gebrakan Awal 2021 Mesin PCR dari Pemkot Tegal Untuk Masyarakat Bebas Covid-19. Diakses tanggal 12 Januari 2021 . https://www.tegalkota.go.id/

Guillot, W Michael. (2003). Strategic Leadership : Defining The Challenge. Air \& Space Winter Journal Vol 17 (4):67-75.

Hanita, Margaretha.(2020). Ketahanan Nasional (Teori, Adaptasi dan Strategi). Jakarta : UI Publishing.

Iqbal, Muhammad.(2020). Bravo! PSBB Berakhir Hari ini, Kota Tegal Nol Kasus Covid-19. Diakses tanggal 10 Januari 2021. Dari cnbcindonesia.com:https://www.cnbcindonesia.co m/news/20200522102657-4-160190/bravo-psbb berakhir-hari-ini-kota-tegal-nol-kasus-covid-19.

Lilisnawati. (2020). Kasus Positif Covid-19 Melonjak, Kota Tegal Siapkan Isolasi Mandiri. Diakses tanggal $13 \quad$ Januari 2021. https://www.ayotegal.com/read/2020/08/10/4445/ kasus-positif-covid-19-melonjak-kota-tegalsiapkan-tempat-isolasi-mandiri.

Lilisnawati.(2020). Wakil Wali Kota Tegal Beberkan Strategi Penanganan Covid-19.diakses tanggal 12 Januari 2021. https://ayosemarang.com/read/2020/08/20/62322/ wakil-wali-kota-tegal-beberkan-strategipenanganan-covid-19.

Nathaniel, Felix.(2020). Tak Hanya di Indonesia: Kepala Daerah Lebih Gesit Tangani COVID-19. Diakses tanggal 11 Januari 2021.https://tirto.id/tak-hanya-di-indonesiakepala-daerah-lebih-gesit-tangani-covid-19-eMxt.

Northhouse, Peter G.(2013). Kepemimpinan Teori dan Praktek. Jakarta : PT. Indeks.

Olson, Aaron K \& Simerson, B Keith. (2015). Leading with Strategic Thinking: Four Ways Effective Leaders Gain Insight, Drive Change, and Get Results. Canada : Wiley.

Peraturan Wali Kota Tegal Nomor 13 Tahun 2020 tentang Pencegahan Corona Virus Disease 2019 (Covid-19) di Kota Tegal.

Peraturan Wali Kota Tegal Nomor 29 Tahun 2020 tentang Perubahan atas Peraturan Wali Kota Tegal Nomor 13 tahun 2020 tentang Pencegahan Penularan Corona Virus Disease 2019 (Covid-19) di Kota Tegal.
Puspitasari. (2016). Komunikasi Krisis : Strategi Mengelola dan Memenangkan Citra di Mata Publik. Jakarta : Penerbit Libri.

Setiadi, Tresno. (2020). Terapkan New Normal, Pemkot Tegal Bubarkan Gugus Tugas Covid-19. Diakses tanggal $14 \quad$ Januari 2021.https://regional.kompas.com/read/2020/06/2 5/21343951/terapkan-new-normal-pemkot-tegalbubarkan-gugus-tugas-covid-19?page=all.

Tm. (2020). Langkah Sigap Pemkot Tegal Atasi Covid19, Berikan Hasil Nyata. Diakses tanggal 11 Januari 2021.

https://jatengprov.go.id/beritadaerah/langkahsigap-pemkot-tegal-atasi-Covid-19-berikan-hasilnyata/.

Tm. (2020). Zona hijau, Kota Tegal Jadi Rujukan DPRD DKI Jakarta Tangani Covid-19. Diakses tanggal 10 Januari 2021. https://jatengprov.go.id/beritadaerah/zona-hijaukota-tegal-jadi-rujukan-dprd-dki-jakarta-tanganicovid-19/.

Worldmeter.(2021). Covid-19 Coronavirus Pandemic. Diakses tanggal 12 Januari 2021.https://www.worldometers.info/coronavirus/. Yoesgiantoro, Donny \& Sumiati. (2018). Pemodelan Sistem Dinamis Economy-Energy dalam Pengurangan Emisi Co2 dan Peningkatan Pdrb untuk Meningkatkan Ketahanan Daerah Banten. Jurnal kajian Stratejik Ketahanan Nasional Vol 1 (2) : 60 . 